\title{
Municipal Treated Wastewater Irrigation: Microbiological Risk Evaluation
}

\author{
Pietro Rubino*, Antonio Lonigro \\ Dipartimento di Scienze delle Produzioni Vegetali, Università di Bari \\ Via Amendola 165/A, 70126 Bari, Italy
}

Received: 5 March 2008. Accepted: 25 July 2008.

\begin{abstract}
Municipal wastewater for irrigation, though treated, can contain substances and pathogens toxic for humans and animals.

Pathogens, although not harmful from an agronomical aspect, undoubtedly represent a major concern with regards to sanitary and hygienic profile. In fact, vegetable crops irrigated with treated wastewater exalt the risk of infection since these products can also be eaten raw, as well as transformed or cooked.

Practically, the evaluation of the microbiological risk is important to verify if the microbial limits imposed by law for treated municipal wastewater for irrigation, are valid, thus justifying the treatments costs, or if they are too low and, therefore, they don' t justify them.

Different probabilistic models have been studied to assess the microbiological risk; among these, the Beta-Poisson model resulted the most reliable.

Thus, the Dipartimento di Scienze delle Produzioni Vegetali of the University of Bari, which has been carrying out researches on irrigation with municipal filtered wastewater for several years, considered interesting to verify if the microbial limits imposed by the italian law n.185/03 are too severe, estimating the biological risk by the probabilistic Beta-Poisson model.

Results of field trials on vegetable crops irrigated by municipal filtered wastewater, processed by the Beta-Poisson model, show that the probability to get infection and/or illness is extremely low, and that the actual italian microbial limits are excessively restrictive.
\end{abstract}

Key-words: Irrigation, microbiological risk, probabilistic model, vegetable crops, wastewater.

\section{Introduction}

Treated municipal wastewater, if used for irrigation, can transport substances and pathogens toxic for humans and animals, arousing some worries about hygienic-sanitary profile (Azzellino and Vismara, 2003).

Among the species irrigated with treated municipal wastewaters, vegetable crops exalt the risk of infection because they can also be eaten raw. In fact, human beings can be exposed to pathogens in many ways:

- consumption of vegetables, mainly raw;

- consumption of meat by livestock fed with products irrigated with wastewaters;
- direct contact with bacterial aerosol spread during irrigation.

The virulence, that is the ability of an organism to induce infection, depends on many factors, environmental and not. One of these is represented by the microrganisms concentration in the environment, whose value is not constant with time, but varies in relation to the number of sick people or healthy carriers. Also, the survival degree of the pathogens in the environment can be very changeable.

Other factors, affecting pathogenicity, are latency period necessary for the micro-organism to become infectious, the minimum infecting dose (minimum number of pathogens able to in-

* Corresponding Author: Tel.: +39 080 5443032; Fax +39 080 5442976. E-mail address: pietro.rubino@agr.uniba.it The research was performed within the project COFIN-PRIN 2004 of the "Ministero dell'Istruzione, dell'Università e della Ricerca”, Rome, Italy.

The Authors contributed equally to the paper. 
duce infection), or sensitivity of the exposed individual.

The data related to the minimum infecting dose are hardly available because of scarce information thus, researchers usually refer to infecting average dose $\left(\mathrm{N}_{50}\right)$, as the amount of pathogens able to infect $50 \%$ of exposed people.

The analytical determination of pathogens presents difficulties of survey, both for variety of existing pathogenic forms and for low concentrations; thus, in most cases they refer to the faecal pollution indicators (total and faecal Coliforms, Escherichia coli, faecal streptococci, Salmonella).

The potential pathogens, resistant to disinfection treatments and contained in the wastewaters used in agriculture, are transferred on soil and crops and can be a potential risk for the health of operators and consumers. The real risk, instead, lower than the potential one, shows the probability that exposed people get sick. While potential risk (WHO, 1989) is exclusively founded on the pathogen number present in the substrate (i.e. irrigation water), the real one considers the survival time of pathogens in water and soil, the minimum infecting dose and the resistance of the exposed person.

The evaluation of the microbial risk is achieved through:

- Epidemiological studies, that study the onset of disease within a population, fixing the relationship between level of exposure and health consequences. Such study, however, has the drawback of a too elevated cost.

- Direct experimentation, that provides inoculation of known quantities of pathogenic micro-organisms or indicators in sample people to verify the infection or disease start. These experiments are usually carried out on guinea pigs and only in rare cases on acquiescent people.

- Use of probabilistic models, which needs limited resources, even if they have to be validated through epidemiological studies.

For risk evaluation, the micro-organism distribution among the doses is assumed to be random and expressible by the probability distribution of POISSON and each micro-organism has the same survival chance (r). In fact, if a person is exposed to the "d" dose (product of the volume $\mathrm{V}$, in which the microrganisms are randomly distributed, and their average density $\mathrm{m}$, constant for all the samples) of micro-organisms present in a water or food sample, the probability $\left(\mathrm{P}_{1}\right)$ of ingesting $\mathrm{N}$ microrganisms is worked out by the POISSON probability equation:

$$
\mathrm{P}_{1(\mathrm{~N} \mid \mathrm{d})}=\frac{(\mu V)^{N}}{N !} \cdot \exp (-\mu V)
$$

Of $\mathrm{N}$ ingested microrganisms, having the same chance of surviving ( $r$ ), the probability that $\mathrm{K}(\mathrm{K}<\mathrm{N})$, survive to give infection, can be calculated by the probability function of binomial frequency:

$$
\mathrm{P}_{2(\mathrm{~K} \mid \mathrm{N} ; \mathrm{r})}=\frac{N !}{K !(N-K) !} r^{K}(1-r)^{N-K}
$$

Particularly, the probability that among the ingested microrganisms at least one gives infection is given by:

$$
\mathrm{P}_{3(\mathrm{~K} \geq \mid \mathrm{N} ; \mathrm{r})}=1-\mathrm{P}_{2(\mathrm{~K}=0 \mid \mathrm{N} ; \mathrm{r})}
$$

This, after some considerations and mathematical simplifications, becomes equal to:

$$
\mathrm{P}_{3}=1-\mathrm{e}^{-\mathrm{rd}}
$$

Being the survival probability factor ( $r$ ) variable, the micro-organisms survival is given by a continuous function $\mathrm{f}(\mathrm{r})$, ranging between 0 and $1(0 \leq r \geq 1)$, whose values are well described by Beta:

$$
\mathrm{f}(\mathrm{r})=\frac{\Gamma(\alpha+\beta)}{\Gamma(\alpha) \Gamma(\beta)} r^{a-1}(1-r)^{\beta-1}
$$

Then, the previous equation $\mathrm{P}_{3}$ is replaced, more correctly, by BETA-POISSON distribution:

$$
\mathrm{P}_{4(\mathrm{~K} \geq 1 \mid \mathrm{d})}=1-\int_{0}^{1} e^{-r d} \frac{\Gamma(\alpha+\beta)}{\Gamma(\alpha) \Gamma(\beta)}(1-r)^{\beta-1} r^{(\alpha-1)} d r
$$

This equation, with large values of $\beta$ ( $\beta$ tending to infinity) and after some transformations and mathematical substitutions to solve the integral, tends to approximate to the equation found by Furumoto and Michey (1967):

$$
\mathrm{P}_{4}=1-(1+\mathrm{d} / \beta)^{-\alpha}
$$

If in the latter equation we substitute the value of $\beta$, worked out in relation to infecting average dose $\mathrm{N}_{50}, \beta=\mathrm{N}_{50} /\left(2^{1 / \mathrm{a}}-1\right)$, it changes to: 


$$
\mathrm{P}_{4}=1-\left[1+\mathrm{d} / \mathrm{N}_{50}\left(2^{1 /}--1\right)\right]^{-\alpha}
$$

which allows to calculate the probability of getting sick $\left(\mathrm{P}_{\mathrm{M}}\right)$, after having got the infection $\left(\mathrm{P}_{\mathrm{I}}\right)$, putting $\mathrm{P}_{\mathrm{M}}=1 / 2 \mathrm{P}_{\mathrm{I}}$.

In order to evaluate the microbiological risk, different probabilistic models were studied, and among them the BETA-POISSON model resulted the most reliable (Azellino and Vismara, 2003).

The Dipartimento di Scienze delle Produzioni Vegetali (DSPV) of Bari University, on the basis of practical knowledge on the irrigation use of treated municipal wastewaters, considered useful to apply this model to the experimental data related to the colimetric values of irrigation waters, in order to give more information on the biological risk.

\section{Materials and methods}

In order to estimate the microbiological risk, lettuce crop was chosen because, besides being consumed raw and soon after the harvest, it is very spread in the feeding of Italian people, it grows near the soil surface and has got an extended wettable leaf surface. To perform the simulation with BETA-POISSON model, the results of a field research carried out on lettuce crop during a two year period $(2004 / 2005)$ at Cerignola (FG), near the municipal wastewater treatment plant, were used.

The lettuce was transplanted in single rows, spacing 0,4X0,4 (Lonigro et al., 2005). The research compared the effects of two types of irrigation waters, tertiary filtered municipal wastewater and artesian well water (control or conventional water), on drip irrigated lettuce crop. The dripping lines were set at each row. Irrigations were performed every time the readily available water in the root layer run out. The faecal pollution indicators (total and faecal Coliforms, faecal Streptococci, Escherichia coli, Salmonella) were analyzed at each irrigation on both the compared water types and at harvest on the lettuce heads picked up from the 8 experimental plots. All the microbial analyses were carried out according to the official methods (Analytical Methods for Waters, 1994, Scharf, 1996). In order to study the effect of the climate on microbial pollution due to the irri- gation with treated municipal wastewater, field experiments were carried out on three lettuce cultivars in succession, grown in three different periods of the year: the first cultivar (Romana) during the summer, from 29/05/04 to 06/07/04, the second cultivar (Rubette) during the autumn, from $16 / 09 / 04$ to $18 / 11 / 04$, the third cultivar (Torlona) in the spring-summer period, from $18 / 03 / 05$ to $01 / 06 / 05$.

In the hypothesis to consider a protective situation, that is with a very high risk, it was hypothesized to irrigate lettuce with sprinkler irrigation method, since a certain amount of water is left on the leaves after irrigation, infecting the crop. This quantity of water was measured in laboratory by weighing leaves before and after irrigation; its amount is around 10 $\mathrm{ml} / 100 \mathrm{~g}$ of lettuce (Shuval, 1997; Asano, 1998; Lonigro, 2006).

Moreover, in order to widen the knowledge about risk probability coming from the consumption of raw lettuce irrigated with municipal wastewater, it was calculated hypothesizing to water lettuce crop with sprinkler method using six different types of waters having different colimetric values, taking four of them from literature:

1) raw municipal wastewater (Escherichia coli/ $\left.100 \mathrm{ml}=10^{7}\right)$

2) biologically treated municipal wastewater ( $E$. coli/100 $\left.\mathrm{ml}=10^{4}\right)$

3) municipal wastewater according to the D.L. 152/99 (Escherichia coli/100 $\left.\mathrm{ml}=5^{*} 10^{3}\right)$;

4) municipal wastewater in accordance with the D.L. 185/03 (E. coli/100 $\mathrm{ml}=10)$;

and two of them coming from the field experiment as said before;

$5)$ tertiary filtered municipal wastewater ( $E$. coli/100 $\mathrm{ml}=11.3)$;

6) well water (Escherichia coli/100 $\mathrm{ml}=7.3$ ).

To define the number $(\mathrm{N})$ of ingested pathogens, as required by the BETA-POISSON model, further hypotheses needed to be defined: 1) the number of Escherichia coli in $100 \mathrm{ml}$, which was $11.3 \pm 3.58$ and $7.3 \pm 2.02$ at $\mathrm{p}=0.05$ in the tertiary filtered wastewater and in well water, as average of the values recorded during the whole irrigation season, respectively; 2) the amount of water wetting lettuce head after irrigation, estimated by Shuval et al. (1977) as 10.8 
$\mathrm{ml} / 100 \mathrm{~g}$ of lettuce, very close to the value observed at the DSPV laboratory (10); 3) the number of Escherichia coli bacteria on lettuce after water evaporation which, as a precaution, was assumed equal to the number found in the wastewater; 4) decrease of Escherichia coli from irrigation to consumption, estimated in $4 \log$ for a period of two weeks by Schwartzbrod (1995) and in $6 \log$ for 3 weeks and after domestic washing. In this case, a conservative decrease estimation decrease of $3 \mathrm{log}$ was adopted; 5) the ratio pathogenic enteric viruses /Escherichia coli, equal to $1: 10^{5}$ (Shuval, 1997). The average time of exposure was hypothesized according to the food customs of southern Italy, that is a daily mean consumption of $100 \mathrm{~g}$ of lettuce for 150 days/year.

Finally, the risk to fall ill $\left(\mathrm{P}_{\mathrm{M}}\right)$ after getting the infection following the ingestion of $100 \mathrm{~g}$ of lettuce, was calculated. Much caution was used also to assess $\mathrm{P}_{\mathrm{M}}$, assuming that the $50 \%$ of infect people fall ill.

The parameters used in BETA-POISSON equation, $\alpha$ and $\mathrm{N}_{50}$, were selected from the literature. Shuval et al. (1997) suggest to set $\alpha=$ 5 and, for high virulence viruses, $\mathrm{N}_{50}=30$. They were determined through epidemiological studies carried out on either guinea-pig samples or persons exposed to increasing doses of Escherichia coli. However, the same authors assert that reducing $\alpha$ to values of 0.2 , the risk doesn't increase appreciably.

\section{Results and discussion}

The results of this two year research showed, in both the compared treatments (membrane filtered municipal wastewater and well water), the total absence of Escherichia coli on the leaves that is total absence of microbial risk.

The results obtained applying the BETAPOISSON model are reported in Table 1, from which one can deduce for each type of compared water, the number of Escherichia coli/100 $\mathrm{mL}$, the number of Escherichia coli/100g of lettuce both after evaporation of water and home washing before eating, the number of ingested pathogenic viruses/100g of lettuce, and the probability of catching both infection $\left(\mathrm{P}_{\mathrm{I}}\right)$ and illness $\left(\mathrm{P}_{\mathrm{M}}\right)$ getting from eating $100 \mathrm{~g}$ of lettuce respectively in one day and during a period of 150 days per year.

With the exposure to wastewater in conformity with the Italian Law n. 185/03, which provides for 10 Escherichia coli $/ 100 \mathrm{~mL}$, the probability of getting illness is equal to 1.85 over 100

Table 1. Infection $\left(\mathrm{P}_{\mathrm{I}}\right)$ and disease $\left(\mathrm{P}_{\mathrm{M}}\right)$ probability following the ingestion of $100 \mathrm{~g}$ of lettuce irrigated with waters with different microbiological quality for high virulence virus $\left(\mathrm{N}_{50}=30\right)$ evaluated by Beta-Poisson model.

\begin{tabular}{|c|c|c|c|c|c|c|c|c|}
\hline $\begin{array}{l}\text { Type of water } \\
\qquad E . c\end{array}$ & $\begin{array}{l}\mathrm{EC}_{\mathrm{AT}} \\
\text { coli/100 mL }\end{array}$ & $\begin{array}{c}\mathrm{EC}_{\mathrm{EV}} \\
\text { E. coli/100 g }\end{array}$ & $\begin{array}{c}\mathrm{EC}_{\mathrm{CO}} \\
\text { E. coli/100 g }\end{array}$ & $\begin{array}{c}\mathrm{N} \\
\text { Virus/100 g }\end{array}$ & $\begin{array}{c}\mathrm{P}_{\mathrm{I}} \\
\text { (1 day) }\end{array}$ & $\begin{array}{c}P_{D} \\
\text { (1 day) }\end{array}$ & $\begin{array}{c}\mathrm{P}_{\mathrm{I}} \\
\text { (150 days) }\end{array}$ & $\begin{array}{c}\mathrm{P}_{\mathrm{M}} \\
\text { (150 days) }\end{array}$ \\
\hline $\begin{array}{l}\text { Raw municipal } \\
\text { Wastewater }\end{array}$ & $10^{7}$ & $10^{6}$ & $10^{3}$ & $10^{-2}$ & $2,4810^{-4}$ & $1,2410^{-4}$ & $3,7110^{-2}$ & $1,8510^{-2}$ \\
\hline $\begin{array}{l}\text { Biologically } \\
\text { treated waste water }\end{array}$ & $10^{4}$ & $10^{3}$ & 1 & $10^{-5}$ & $2,4710^{-7}$ & $1,2410^{-7}$ & $3,7110^{-5}$ & $1,8510^{-5}$ \\
\hline $\begin{array}{l}\text { Wastewater } \\
\text { in accordance } \\
\text { to D.L. } 152 / 99\end{array}$ & $510^{3}$ & $510^{2}$ & $510^{-1}$ & $510^{-6}$ & $1,2310^{-7}$ & $6,210^{-8}$ & $1,8510^{-5}$ & $9,2910^{-6}$ \\
\hline $\begin{array}{l}\text { Wastewater } \\
\text { in accordance } \\
\text { to D.L. } 185 / 03\end{array}$ & 10 & 1 & $10^{-3}$ & $10^{-8}$ & $2,4710^{-10}$ & $1,2410^{-10}$ & $3,7110^{-8}$ & $1,8510^{-8}$ \\
\hline $\begin{array}{l}\text { Experimental Data } \\
\text { Tertiary filtered } \\
\text { municipal wastewat }\end{array}$ & $\begin{array}{l}11,3 \\
\text { ter }\end{array}$ & 1,1 & $1,1310^{-3}$ & $1,1310^{-8}$ & $2,8 \quad 10^{-10}$ & $1,4 \quad 10^{-10}$ & $4,210^{-8}$ & $2,110^{-8}$ \\
\hline Well water & 7,3 & 0,7 & $7,310^{-4}$ & $7,310^{-9}$ & $1,8110^{-10}$ & $910^{-11}$ & $2,7110^{-8}$ & $1,3610^{-8}$ \\
\hline \multicolumn{9}{|c|}{$\begin{array}{l}\mathrm{EC}_{\mathrm{AT}}=\text { Escherichia coli in six types of water. } \\
\mathrm{EC}_{\mathrm{EV}}=\text { Escherichia coli on leaves after water evaporation. } \\
\mathrm{EC}_{\mathrm{CO}}=\text { Escherichia coli decrease from irrigation to consumption }\end{array}$} \\
\hline
\end{tabular}


millions people exposed per year: the same result was obtained irrigating vegetables with well water.

The results of this two year research carried out on three cultivars of lettuce drip irrigated showed, in both the compared treatments (membrane filtered municipal wastewater and well water), the total absence on the leaves of Escherichia coli, that is total absence of microbial risk. The absence of risk was also monitored when the climatic conditions of crop growing changed.

While consuming sprinkler irrigated lettuce, there is the probability, even if very low, to be infected from the microrganisms remaining on the leaves. The results, in fact, indicate that the probability to get infection and/or illness, apart from raw wastewater, ranges from $1.85^{*} 10^{-5}$ to $1.36^{*} 10^{-8}$. For well water and treated municipal wastewater, the probability of getting infection and/or illness ranges from $1.36^{*} 10^{-8}$ to $2.1^{*} 10^{-8}$, respectively.

The observed results are similar to those obtained by Haas et al. (1999) and Shuval et al. (1997) for treated and disinfected wastewater for irrigation, but they are 10 times lower than the results obtained by Asano et al. (1990) using the same type of wastewater. Moreover, they agree with the probabilistic models, particularly with BETA-POISSON model, applied to field scale. These models, opportunely improved, could contribute, in the next future, to a better definition of the microbiological limits for the wastewater reuse in agriculture.

\section{Conclusions}

A two year research carried out in southern Italy to study microbiological risk due to eating lettuce drip irrigated with membrane filtered municipal wastewater and well water, sprinkler irrigated with the previous two and other four types of water of worst quality, allows the following conclusions.

The assessment of the microbiological risk by the deterministic model BETA-POISSON pointed out that the probability of getting illness ingesting raw vegetables sprinkle irrigated with municipal wastewater treated according to the limits of current Italian law is negligible, and it would be almost zero replacing sprinkle irrigation with drip irrigation. Besides, even chang- ing lettuce crop growing season, i.e. from summer to autumn, the risk of getting sick, eating lettuce both drip and sprinkle irrigated using the same wastewaters, remains unchanged. Therefore, it would be useful to re-examine these colimetric limits, increasing them, in the viewpoint of reducing considerably the depuration costs and thus allowing the reuse in agriculture protecting environment and reducing public expenditure.

\section{Reference}

Asano T. 1998 (ed.). Wastewater Reclamation and Reuse. Water Quality Management Library Vol. 10. Technomic Publishing Inc., Lancaster, Pennsylvania, USA.

Asano T., Sakaji R.H. 1990. Virus Risk Analysis in Wastewater Reclamation and Reuse. In: Hahn H.H., Klute R. (eds.): Chemical Water and Wastewater Treatment, 483-496. Springer-Verlag, Berlin, Germany.

Azzellino A., Vismara R. 2003. Modelli di valutazione del rischio biologico: applicazione al caso del riuso irriguo dei liquami. Biologi Italiani, 4:53-67.

Decreto Legge n. 152 dell'11 maggio 1999. Disposizioni sulla tutela delle acque dall'inquinamento e recepimento della direttiva 91/676/CEE. Supplemento ordinario alla Gazzetta Ufficiale n. 177 del 30 luglio 1999, serie Generale.

Decreto Legge n. 185 del 12 giugno 2003. Regolamento recante norme tecniche per il riutilizzo delle acque reflue in attuazione dell'art. 26, comma 2, del D.L. 11 maggio 1999, n. 152. Supplemento ordinario alla Gazzetta Ufficiale n. 169 del 23 luglio 2003, serie Generale.

Furumoto W.A., Michey M. 1967. A mathematical model for the infectivity-dilution curve of Tabacco Mosaic Virus: Theoretical Considerations. Virology, 32:216223.

Haas C.N., Rose J.B., Gerba C.P. 1999. Quantitative Microbial Risk Assesment. John Wiley \& Sons. Inc.

Lonigro A. 2006. Studio sugli aspetti igienico-sanitari connessi al riutilizzo di acque reflue depurate a scopo irriguo. Tesi di Dottorato di ricerca in "Agronomia Mediterranea” XVIII Ciclo, Università di Bari.

Lonigro A., Rubino P., Brandonisio O., Spinelli R., Pollice A. 2005. Vegetable crops irrigation with filtered municipal wastewater: microbial aspects. Proceeding of WATMED2, 14-17 November, Marrakesh.

Metodi analitici per le acque, 1994. IRSA-CNR, Istituto Poligrafico e Zecca dello Stato - Libreria dello Stato, Quaderno n. 100:314-329.

Scharf J.M. 1996. Recommended methods for the microbiological examination of foods. APHA, $2^{\text {nd }}$ Edition, New York. 
Schwartzbrod L. 1995. Risk evaluation criteria. Effect of human viruses on public health associated with the use of wastewater and sawage sludge in agricolture. Geneva, WHO.

Shuval H., Lambert Y., Fattal B. 1997. Development of a risk assesment approach for evaluating wastewater reuse standards for agricolture. Wat. Sci. Tech., 35, 11-12:15-20.

World Health Organization (WHO) 1989. Health guidelines for the use of wastewater in agricolture and aquaculture. WHO Technical Report n. 778, Geneve. 